American Journal of Applied Sciences 6 (10): 1800-1806, 2009

ISSN 1546-9239

(C) 2009 Science Publications

\title{
Identification and Antiproliferative Activity Evaluation of a Series of Triterpenoids Isolated from Flueggea virosa (Roxb. ex Willd.)
}

\author{
${ }^{1}$ Sod Monkodkaew, ${ }^{1}$ Chatchanok Loetchutinat, ${ }^{2}$ Narong Nuntasaen and ${ }^{1}$ Wilart Pompimon \\ ${ }^{1}$ Laboratory of Natural Products, Department of Chemistry, Faculty of Science, Lampang Rajabhat \\ University and Center of Excellence for Innovation in Chemistry (PERCH-CIC), Lampang 52100 Thailand \\ ${ }^{2}$ The Forest Herbarium, Department of National Park, Wildlife and Plant Conservation, \\ Ministry of Natural Resources and Environment, Bangkok 10900 Thailand
}

\begin{abstract}
Problem statement: Medicinal plants derived anticancer were now being subjects of many research groups especially, the secondary metabolite triterpenoids trees which had enormous potential to inspire and influence modern antiproliferative research. The study aimed to investigate the chemical constitution and their potential use as antiproliferative activity of purified compounds derived from $F$. virosa. Approach: The $F$. virosa was selected and percolated with hexane, ethyl acetate, acetone and methanol. The extracts were purified and elucidated chemical structures. Furthermore, the isolated compounds were tested for biological activity. The bioassays were performed on two cancer cell lines, adriamycin-sensitive erythroleukemia cells (K562) and adriamycin-resistant erythroleukemia cells (K562/Adr) which overexpressed P-glycoprotein (MDR1/ABCB1). Results: Friedelin (1), epifriedelanol (3), stigmasterol (4) and betulinic acid (5) were isolated from the leaves and twigs of $F$. virosa. The molecular structures of these compounds were determined using several spectroscopic methods. The compounds i.e., 1, a chemically modified compound 1 heptanolide (2), 3 and 4 showed a limited cytotoxic activity towards human cancer cell lines mainly due to a low aqueous solubility which prevented their use in cell viability assays. Interestingly, compound 5 exhibited a high cytotoxicity characterized by an effective concentration value $\left(\mathrm{IC}_{50}\right)$ equal to $9.7 \pm 2.1 \mu \mathrm{g} \cdot \mathrm{mL}^{-1}(21.2 \pm 4.6 \mu \mathrm{M})$ and $7.1 \pm 0.7 \mu \mathrm{g} \cdot \mathrm{mL}^{-1}(15.5 \pm 1.5 \mu \mathrm{M})$ for $\mathrm{K} 562$ and K562/Adr, respectively. Moreover, the antiproliferative activity of compound 5 was independent of the multidrug resistance phenotype exhibited by the K562/Adr cell line suggesting that compound 5 was not the effluxes out of the K562/Adr cells by MDR1 (ABCB1). Conclusion: The results clearly showed that the betulinic acid of the four isolated compounds from $F$. virosa could be considered as high potential source of cytotoxic activity.
\end{abstract}

Key words: Triterpenoids, betulinic acid, antiproliferation, Flueggea virosa

\section{INTRODUCTION}

Genus Flueggea, belonging to the Euphorbiaceae family, contains 4 species were $F$. acidoton, $F$. neowawraea, $F$. tinctoria and $F$. virosa, which are shrubs and widely distributed among the tropical forests. Extensive survey of the genus Flueggea by smittinand ${ }^{[1]}$ indicated the presence of $F$. virosa single in Thailand.

The significant biological activities of extracts and important ethnomedical applications of $F$. virosa include, antimalarial $^{[2,3]}, \quad$ antidiabetic $^{[4,5]}$, antimicrobial ${ }^{[6]}$, antidirrhoeal $^{[7]}$, antioxidant ${ }^{[6]}$, chemotaxomic ${ }^{[8]}$, antiarrhythmic $^{[9]}$, sedative ${ }^{[10]}$, antitrypanosomal ${ }^{[11]}$ and anticonvulsant ${ }^{[12]}$. Previous chemical studies of $F$. virosa showed that tannins, flavonoids, saponins ${ }^{[4,7,10]}$, resin, glycosides, glycerin carbohydrate, anthraquine, steroids $^{[4]}, \quad$ alkaloids ${ }^{[7,11]}$ cardiac glycosides $^{[4,7]}$, anthraquinone ${ }^{[7]}$, norsecurinine ${ }^{[13]}$, pipecolinic acid ${ }^{[14]}$, bergenin $^{[8,9]}, 14,15$-epoxynorsecurinine, norsecurinine ${ }^{[15]}$, virosecurinine ${ }^{[16,17]}$, viroallosecurinine $e^{[17]}$, friedelin, friedelan-3 $\alpha$-ol, friedelan-3 $\beta$-ol, lupeol, glochidonol, glochilocudiol, betulonic acid and sitosterol ${ }^{[18]}$ were chemical constituent of $F$. virosa. As part of our ongoing project on the discovery of new anti-cancer agents from $F$. virosa.

In this task, the hexane and ethyl acetate fraction of Flueggea virosa (Roxb. ex Willd.) was studied and led to the isolation of friedelin (1), epifriedelanol (3), stigmasterol (4) and betulinic acids (5), in addition heptanolide (2) was modification from friedelin (1) (Fig. 1).

Corresponding Author: Wilart Pompimon, Laboratory of Natural Products, Department of Chemistry, Faculty of Science, Lampang Rajabhat University and Center of Excellence for Innovation in Chemistry (PERCH-CIC), Lampang, 52100 Thailand Tel/Fax: +665-3241052 

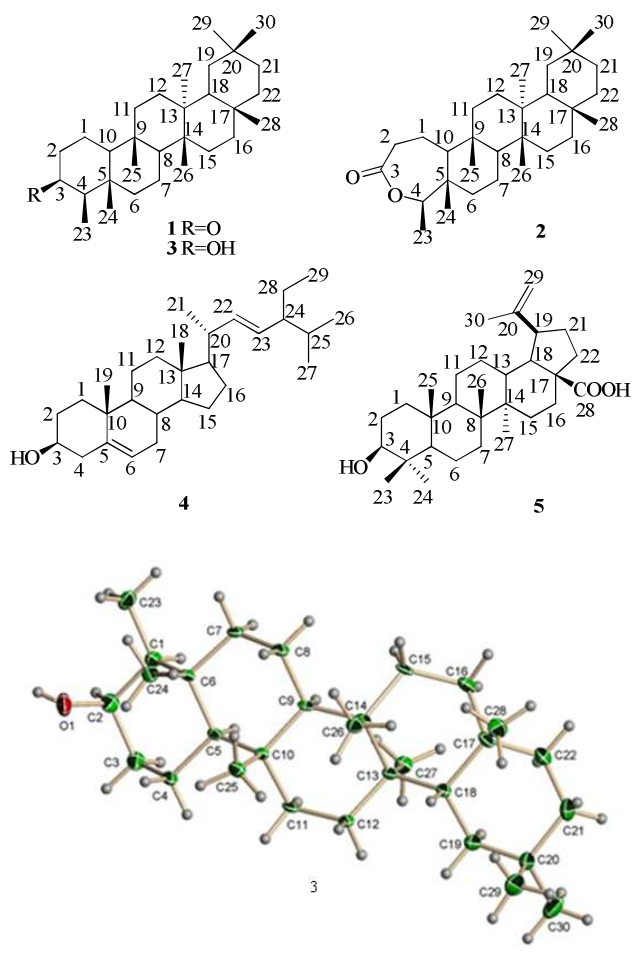

Fig. 1: Structures of compounds 1-5 and X-ray ORTEP diagram of 3

The structures of all compounds were elucidated on the basis of spectroscopic methods. We herein describe the isolation, the modification and determination of the structures, including their anticancer activities.

\section{MATERIAL AND METHODS}

Plant material: The leaves and twigs of $F$. virosa were collected from Suratthani Province of Thailand in January, 2008. A voucher specimen (BKF no. 129958) has been deposited at the Forest Herbarium, Department of National Park, Wildlife and Plant Conservation, Ministry of Natural Resources and Environment, Bangkok, Thailand.

General procedures: Mps: uncorr.; UV: $\mathrm{MeOH}$; IR: $\mathrm{KBr}$. NMR spectra were recorded on a Brüker DPX 400 in $\mathrm{CDCl}_{3}$ or Pyridine-d5 using TMS as an internal standard and X-ray diffraction, otherwise stated; CC was carried out on silica 60, 70-230 mesh.

Extraction and isolation: The air-dried and finely powdered leaves and twigs of $F$. virosa $(3.6 \mathrm{~kg})$ were successively percolated with hexane $(7 \mathrm{~L} \times 3$ days $\times 7$ times), ethyl acetate (7 L $\times 3$ days $\times 18$ times), acetone (7
$\mathrm{L} \times 3$ days $\times 13$ times) and methanol ( $7 \mathrm{~L} \times 3$ days $\times 7$ times) at room temperature, followed by filtration. The filtrates were combined and evaporated to dryness under reduced pressure to afford hexane extract $(28.9 \mathrm{~g})$, ethyl acetate extract $(70.0 \mathrm{~g})$, acetone extract $(86.70 \mathrm{~g})$ and a methanol extract $(267.85 \mathrm{~g})$, respectively. The hexane extract $(28.90 \mathrm{~g})$ was separated by CC over silica gel $(350 \mathrm{~g})$. Gradient elution was conducted initially with n-hexane, gradually enriched with ethyl acetate (100:0, 95:5, 90:10, 80:20, 50:50, 30:70, 0:100), followed by increasing amount of ethyl acetate in methanol $(80: 20,50: 50, \quad 0: 100)$. Fractions were collected and combined on the basis of their TLC behavior. The solvents were evaporated to dryness to afford ten fractions $\mathrm{F}_{1}-\mathrm{F}_{10}$. Rechromatographed subfraction $\mathrm{F}_{2}+\mathrm{F}_{3}(14.92 \mathrm{~g})$, eluted by $5 \%$ EtOAc-nhexane. Gradient elution was pure n-hexane-EtOAc $(100: 0,95: 5,90: 10)$ afford subfractions $A_{1}-A_{5}$. Repeated CC of $\mathrm{A}_{2}(4.65 \mathrm{~g})$ to afford subfractions $\mathrm{C}_{1^{-}}$ $\mathrm{C}_{2}$, subtractions $\mathrm{C}_{1}(0.18 \mathrm{~g})$ was further purified by recrystallized afford $1(0.14 \mathrm{~g})$. Subfraction $\mathrm{A}_{3}(5.59 \mathrm{~g}$, eluted with hexane) was rechromatographed on a silica gel column. Elution with hexane- EtOAc (100:0, 95:5) to afford four subfractions $\left(\mathrm{E}_{1}-\mathrm{E}_{4}\right)$. Repeated $\mathrm{CC}$ of $\mathrm{E}_{1}+\mathrm{E}_{2}(2.50 \mathrm{~g}$, eluted with hexane) over silica gel. Elution with hexane- EtOAc (100:0, 95:5) gradients to afford $\mathrm{G}_{1}-\mathrm{G}_{3}$. Subfraction $\mathrm{G}_{2}(0.84 \mathrm{~g})$, eluted by pure $\mathrm{n}$ hexane, recrystallized obtain pure compound $3(0.46 \mathrm{~g})$. Rechromatography of subfraction $\mathrm{E}_{3}(1.61 \mathrm{~g})$ was performed on silica gel. Gradient elution with nhexane-EtOAc (95:5) to afford subfractions $\mathrm{H}_{1}-\mathrm{H}_{3}$, subfraction $\mathrm{H}_{2}(0.61 \mathrm{~g})$, recrystallized obtain pure compound $4(0.08 \mathrm{~g})$. The ethyl acetate extract $(70.00$ g) was separated by $\mathrm{CC}$ over silica gel $(650 \mathrm{~g})$. Gradient elution was also of isolation hexane extract. Fractions were collected all fractions were monitored by TLC and combined on the basis of their TLC characteristics. The solvents were evaporated to dryness to afford fractions $\mathrm{I}_{1}-\mathrm{I}_{4}$. Subfraction $\mathrm{I}_{3}(4.66 \mathrm{~g}, 10 \%$ EtOAc-hexane) was rechromatographed on a silica gel column. Elution with n-hexane-EtOAc (100:0, 95:5, 90:10, 80:20) gradients to afford $K_{1}-K_{3}$, subfraction $K_{2}$ $(1.88 \mathrm{~g})$ was rechromatographed one time to afford 5 $(1.33 \mathrm{~g})$. The isolated 1 was modified, hence the oxidative transformation of ring A of 1 was undertaken. The Baeyer Villiger oxidation of $1(50 \mathrm{mg})$ with MCPBA in $\mathrm{CH}_{2} \mathrm{Cl}_{2}$ at room temperature for overnight afforded the heptanolide (2) (60\% yield).

Cell culture and cell viability assay: Cell viability assays were performed on two cancer cell lines, adriamycin-sensitive erythroleukemia cells (K562) and adriamycin-resistant erythroleukemia cells (K562/Adr) 
which overexpressed P-glycoprotein (MDR1/ABCB1). The K562/Adr cells were cultured in RPMI-1640 medium supplemented with $10 \%$ fetal bovine serum, $1 \%$ antibiotic and $100 \mathrm{nM}$ doxorubicin at $37^{\circ} \mathrm{C}$ and $5 \%$ $\mathrm{CO}_{2}$ for 3 days. Then, cells were grown in doxorubicin free medium for 2 weeks before cell viability experiments. Both cell lines were cultivated in the free compound medium and growth inhibition curves were generated using various concentrations of 4 purified compounds from $F$. virosa and a modification compound. Cell viability was determined using the 3 (4, 5-dimethylthiazol-2-yl)-2, 5-diphenyltetrazolium bromide (MTT) reduction. The formazan crystal production from MTT reduction was determined by measuring the absorption at $560 \mathrm{~nm}$ which correlates with the number of living cells. The percentage of growth inhibition was calculated and plotted versus the concentration of the compound tested. The antiproliferative ability of a compound against cancer cell proliferation was expressed as the concentration of compound needed to inhibit by $50 \%\left(\mathrm{IC}_{50}\right)$ the cellular proliferation.

\section{RESULTS}

Chemical structure identification of compounds: The chemical structure of isolated compounds from $F$. virosa and modified compound i.e., friedelin (1), epifriedelanol (3), betulinic acid (5) and heptanolide (2), were identified as follow:

Friedelin (1): White needles from $\mathrm{CH}_{2} \mathrm{Cl}_{2}$ : $\mathrm{MeOH}$, m.p. 258.1-261.3 ${ }^{\circ} \mathrm{C}\left(\mathrm{Lit}^{[19]}\right.$ m.p. $\left.262-263^{\circ} \mathrm{C}\right)$. IR (KBr) $v_{\max }$ : 1715 ( $\mathrm{C}=\mathrm{O}$ stretching of ketone), 2927, 2870, 1463, $1390 \mathrm{~cm}^{-1}$. ${ }^{1} \mathrm{H}$ and ${ }^{13} \mathrm{C}-\mathrm{NMR}$ data: Table 1. COSY correlations H/H: 4/23. HMBC correlations: Table 2. EIMS (70 eV) m/z (\%): $426\left(\mathrm{M}^{+}, 39\right), 411$ (13), 341(34), 302 (22), 273 (69), 246 (81), 231 (62), 189 (53), 161 (67), 121 (70), 109 (100), 95 (76), 81 (88), 67 (84).

Table 1: $400 \mathrm{MHz}{ }^{1} \mathrm{H}$-and $150 \mathrm{MHz}{ }^{13} \mathrm{C}-\mathrm{NMR}$ data of compound 1, 2, 3 and $5\left(\mathrm{CDCl}_{3}\right.$ and Pyridine-d5) (cont.)

\begin{tabular}{|c|c|c|c|c|c|c|c|c|}
\hline \multirow[b]{2}{*}{ Position } & \multicolumn{4}{|l|}{$\delta_{\mathrm{H}}$} & \multicolumn{4}{|l|}{$\delta_{\mathrm{C}}$} \\
\hline & $1^{\mathrm{a}}$ & $2^{\mathrm{a}}$ & $3^{a}$ & $5^{\mathrm{b}}$ & $1^{\mathrm{a}}$ & $2^{\mathrm{a}}$ & $3^{\mathrm{a}}$ & $5^{\mathrm{b}}$ \\
\hline 1 & $1.99(\mathrm{~m})$. & 1.25 (obsc.) & 1.39 (obsc.) & 1.68 (obsc.) & 22.30 & 29.71 & 17.50 & 37.95 \\
\hline 2 & $2.42(\mathrm{dd}, 5.1,1.9)$ & $\begin{array}{l}\text { (a) } 2.64 \\
\text { (dd,13.4,6.6) } \\
\text { (br) } 2.52(\mathrm{t}, 12.8)\end{array}$ & $\begin{array}{l}\text { (a) } 1.45 \text { (obsc.) } \\
\text { (b) } 0.96 \text { (obsc.) }\end{array}$ & 1.23(obsc.) & 41.54 & 34.36 & 35.03 & 28.95 \\
\hline 3 & - & - & $3.73(\mathrm{~d}, 2)$ & $3.46(\mathrm{~m})$ & 213.32 & 175.60 & 72.77 & 78.44 \\
\hline 4 & $2.25(\mathrm{q}, 6.4)$ & $4.22(\mathrm{q}, 6.4)$ & 1.26(obsc.) & - & 58.23 & 84.94 & 49.17 & 41.41 \\
\hline 5 & - & - & - & 1.40(obsc.) & 42.16 & 58.24 & 37.10 & 51.26 \\
\hline 6 & 1.77(obsc.) & 1.27(obsc.) & $\begin{array}{l}\text { (a) } 1.73 \\
\text { (d(t) } 12.8,3.1) \\
\text { (b) } 1.00 \text { (obsc.) }\end{array}$ & 1.57(obsc.) & 41.29 & 41.30 & 41.72 & 19.08 \\
\hline 7 & 1.52 (obsc.) & $\begin{array}{l}\text { (a) } 1.93 \\
\text { (dd,14.6, } 7.4 \text { ) } \\
\text { (b) } 1.49 \text { (obsc.) }\end{array}$ & 1.42 (obsc.) & 1.42(obsc.) & 18.24 & 18.24 & 15.79 & 35.13 \\
\hline 8 & 1.41(obsc.) & 1.30 (obsc.) & 1.29 (obsc.) & - & 53.10 & 52.73 & 53.20 & 39.81 \\
\hline 9 & - & - & - & 0.83(obsc.) & 37.45 & 37.45 & 37.83 & 56.22 \\
\hline 10 & 1.55 (obsc.) & 1. 12(obsc.) & 0.92 (obsc.) & - & 59.47 & 64.00 & 61.34 & 37.81 \\
\hline 11 & 1.25 (obsc.) & 1.18(obsc.) & 1.91(obsc.) & 1.23(obsc.) & 35.63 & 35.63 & 35.34 & 21.51 \\
\hline 12 & 1.35(obsc.) & 1.34(obsc.) & 1.30 (obsc.) & 1.95(obsc.) & 30.51 & 30.60 & 30.64 & 26.42 \\
\hline 13 & - & - & - & 1.65 (obsc.) & 39.70 & 39.35 & 39.67 & 39.59 \\
\hline 14 & - & - & - & - & 38.30 & 38.39 & 38.37 & 43.15 \\
\hline 15 & 1.18(obsc.) & 1.18(obsc.) & 1.14(obsc.) & 1.87(obsc.) & 32.42 & 32.37 & 32.33 & 28.54 \\
\hline 16 & 0.98 (obsc.) & 0.94(obsc.) & 1.20 (obsc.) & $2.64(\mathrm{~d}, 12.69)$ & 36.01 & 35.97 & 36.08 & 31.54 \\
\hline 17 & - & - & - & - & 30.03 & 29.99 & 30.03 & 56.99 \\
\hline 18 & 1.58 (obsc.) & 1.57(obsc.) & 1.57(obsc.) & 1.76 (obsc.) & 42.79 & 42.73 & 42.81 & 50.08 \\
\hline 19 & 0.98(obsc.) & 0.93(obsc.) & 1.88(obsc.) & $3.54(\mathrm{~m})$ & 35.35 & 35.31 & 35.18 & 48.07 \\
\hline 20 & - & - & - & - & 28.18 & 28.16 & 28.18 & 151.71 \\
\hline 21 & 1.20 (obsc.) & 1.20 (obsc.) & 1.52 (obsc.) & 2.26(obsc.) & 32.77 & 32.75 & 32.81 & 30.59 \\
\hline 22 & 0.95 (obsc.) & $\begin{array}{l}\text { (a) } 1.48 \text { (obsc.) } \\
\text { (b) } 0.95 \text { (obsc.) }\end{array}$ & 1.47(obsc.) & 1.57(obsc.) & 39.26 & 39.23 & 39.28 & 38.88 \\
\hline 23 & $0.89(\mathrm{~d}, 8)$ & $1.21(\mathrm{~s})$ & $0.94(\mathrm{~s})$ & 1.23(obsc.) & 6.83 & 16.20 & 11.63 & 28.54 \\
\hline 24 & $0.73(\mathrm{~s})$ & $0.88(\mathrm{~s})$ & $0.98(\mathrm{~s})$ & $1.08(\mathrm{~s})$ & 14.66 & 13.44 & 16.40 & 15.20 \\
\hline 25 & $0.87(\mathrm{~s})$ & $0.83(\mathrm{~s})$ & $0.88(\mathrm{~s})$ & $1.08(\mathrm{~s})$ & 17.95 & 17.90 & 18.25 & 16.73 \\
\hline 26 & $1.01(\mathrm{~s})$ & $1.00(\mathrm{~s})$ & $0.99(\mathrm{~s})$ & 0.83 (obsc.) & 20.26 & 20.20 & 20.13 & 16.65 \\
\hline 27 & $1.05(\mathrm{~s})$ & $0.99(\mathrm{~s})$ & 1.00 (obsc.) & $1.08(\mathrm{~s})$ & 18.68 & 18.58 & 18.66 & 16.73 \\
\hline 28 & 1.18(obsc.) & $1.17(\mathrm{~s})$ & $1.19(\mathrm{~s})$ & - & 32.10 & 32.05 & 32.09 & 179.66 \\
\hline 29 & 0.95 (obsc.) & 0.95(obsc.) & 1.00 (obsc.) & $\begin{array}{l}\text { (a) } 4.78(\mathrm{~s}) \\
\text { (b) } 4.95(\mathrm{~s})\end{array}$ & 35.03 & 35.02 & 31.80 & 110.20 \\
\hline 30 & 1.01 (s.) & 1.00 (s.) & 0.96 (obsc.) & $1.80(\mathrm{~s})$. & 31.79 & 31.75 & 35.00 & 19.78 \\
\hline
\end{tabular}


Am. J. Applied Sci., 6 (10): 1800-1806, 2009

\begin{tabular}{|c|c|c|c|c|}
\hline $\mathrm{C}$ & 1 correlated $\mathrm{H}$ & 2 correlated $\mathrm{H}$ & 3 correlated $\mathrm{H}$ & 5 correlated $\mathrm{H}$ \\
\hline 1 & 2 & - & $2 b, 3$ & $25,9,3,5$ \\
\hline 2 & 1 & - & 4 & 3 \\
\hline 3 & $2,1,23,4$ & $2 \mathrm{a}, 2 \mathrm{~b}, 4$ & $2 b, 2 a, 23$ & $1,2,23,24$ \\
\hline 4 & $2,23,24$ & $4,10,23,24$ & $23,2 b, 24,6 b$ & $2,23,24,5,6$ \\
\hline 5 & $4,1,23,24$ & 24 & $3,23,24$ & $23,24,7,9,25$ \\
\hline 6 & 24 & $24,10,7 a, 7 b$ & 24 & 5,7 \\
\hline 7 & 8 & 6,8 & - & 6 \\
\hline 8 & $25,7,26,10,11,6$ & 25,26 & $25,6 \mathrm{a}, 7,6 \mathrm{~b}, 26,15$ & $7,27,26,11,9$ \\
\hline 9 & 25 & $25,7,11$ & 8,12 & $5,7,26,11,1$ \\
\hline 10 & $2,4,24,25,8$ & $1,2 \mathrm{a}, 2 \mathrm{~b}, 4,24,6,8,25$ & $2 \mathrm{~b}, 4,24,25,8,11$ & $9,25,1,5,6)$ \\
\hline 11 & 25 & 10,25 & 25 & 12 \\
\hline 12 & 11,27 & $11,27,18$ & 27 & 13 \\
\hline 13 & $27,26,15$ & $18,27,11,12,8,26,15,19$ & 27,26 & $11,18,27$ \\
\hline 14 & 27,26 & $27,12,8,26,16,7$ & $27,26,8$ & $15,16,18,27$ \\
\hline 15 & 26,16 & 26,16 & 26 & 27 \\
\hline 16 & 15,28 & $15,28,22 \mathrm{a}, 22 \mathrm{~b}$ & 28 & - \\
\hline 17 & $28,15,16,21,19$ & $15,16,18,22 \mathrm{~b}, 28,19$ & $28,18,16$ & $16,18,21,22$ \\
\hline 18 & 28,27 & $27,12,16,28,22 \mathrm{~b}, 19$ & $28,16,27$ & 16 \\
\hline 19 & $29,21,30$ & 29,30 & 29,30 & $18,21,29 a, 29 b, 30$ \\
\hline 20 & $19,29,30,22$ & $29,30,19$ & 29,30 & $29 \mathrm{a}, 29 \mathrm{~b}, 30,18,19$ \\
\hline 21 & $19,29,30,22$ & $29,30,19,22 \mathrm{~b}$ & 29,30 & - \\
\hline 22 & 21,28 & $16,18,28$ & 16,28 & 18 \\
\hline 23 & 4 & 4 & - & 3 \\
\hline 24 & 4 & 4 & - & 23 \\
\hline 25 & - & 8,11 & - & 9 \\
\hline 26 & 8,15 & 8 & 8 & 9 \\
\hline 27 & 18,12 & 12,18 & 18 & - \\
\hline 28 & 22,16 & $16,18,22 \mathrm{a}, 22 \mathrm{~b}$ & - & 18,22 \\
\hline 29 & 30,21 & 19,30 & - & 30 \\
\hline 30 & 29,19 & 19,29 & - & $29 a, 29 b$ \\
\hline
\end{tabular}

Heptanolide (2): White needles from $\mathrm{CH}_{2} \mathrm{Cl}_{2}: \mathrm{MeOH}$, m.p. $249.9-252.3^{\circ} \mathrm{C}$. IR $(\mathrm{KBr}) v_{\max }: 1737(\mathrm{C}=\mathrm{O}$ stretching of lactone), 2930, 2868, 1464, $1385 \mathrm{~cm}^{-1}$. ${ }^{1} \mathrm{H}$ and ${ }^{13} \mathrm{C}-\mathrm{NMR}$ data: Table 1 . COSY correlations H/H: 2a/2b; 4/23; 7a/7b; 22a/22b. HMBC correlations: Table 2. EIMS $(70 \mathrm{eV}) \mathrm{m} / \mathrm{z}(\%): 442\left(\mathrm{M}^{+}, 23\right), 426$ (13), 398 (23), 383 (38), 274 (65), 245 (43), 218 (68), 204 (67), 189 (57), 161 (53), 149 (39), 121 (82), 95 (100), 67 (97).

Epifriedelanol (3): White needles from $\mathrm{CH}_{2} \mathrm{Cl}_{2}$ : $\mathrm{MeOH}$, m.p. $281.2-282.6^{\circ} \mathrm{C}$. IR (KBr) $v_{\max }: 3475(\mathrm{OH}$ stretching), 2933-2869, 1457, $1386 \mathrm{~cm}^{-1} .{ }^{1} \mathrm{H}$ and ${ }^{13} \mathrm{C}-$ NMR data: Table 1. COSY correlations $\mathrm{H} / \mathrm{H}$ : 4/23; 19/18; 2b/2a; 6a/6b. HMBC correlations: Table 2. EIMS $(70 \mathrm{eV}) \mathrm{m} / \mathrm{z}(\%): 428\left(\mathrm{M}^{+}, 12\right), 413$ (50), 395 (25), 275 (34), 257 (40), 233 (57), 206 (51), 191 (41), 165 (96), 147 (67), 121 (75), 109 (80), 95 (93), 67 (100).

Stigmasterol (4): ${ }^{[20]}$ White needles from $\mathrm{CH}_{2} \mathrm{Cl}_{2}$ : $\mathrm{MeOH}$ m.p. $145.8-148.9^{\circ} \mathrm{C}$. IR (KBr) $v_{\max }: 3430(\mathrm{OH}$ stretching), 1639-1655 (C = C stretching), 2938-2867, 1464, 1383-1368. $\mathrm{cm}^{-1} .{ }^{1} \mathrm{H}-\mathrm{NMR} 400 \mathrm{MHz}, \mathrm{CDCl}_{3}: \delta$ $1.87(1 \mathrm{H}$, obsc, $\mathrm{H}-1 \mathrm{a}), 1.84(1 \mathrm{H}$, obsc, $\mathrm{H}-1 \mathrm{~b}), 1.52(2 \mathrm{H}$, obsc, H-2), $3.53(1 \mathrm{H}, \mathrm{m}, \mathrm{H}-3), 2.29(1 \mathrm{H}$, obsc, H-4), $5.35(1 \mathrm{H}, \mathrm{d}, \mathrm{J}=4.92 \mathrm{~Hz}, \mathrm{H}-6), 2.03(1 \mathrm{H}$, obsc, $\mathrm{H}-7 \mathrm{a})$,
$1.53(1 \mathrm{H}$, obsc, H-7b), $0.93(1 \mathrm{H}$, obsc, $\mathrm{H}-8), 0.95(1 \mathrm{H}$, obsc, H-9), 1.53 (2H, obsc, H-11), $1.16(2 \mathrm{H}$, obsc, H12), 1.07 (1H, obsc, H-14), 1.57 (2H, obsc, H-15), 1.19 $(2 \mathrm{H}$, obsc, H-16), $1.08(1 \mathrm{H}$, obsc, $\mathrm{H}-17), 0.70(3 \mathrm{H}, \mathrm{s}$, $\mathrm{H}-18), 1.01$ (3H, s, H-19), 2.04 (1H, obsc, H-20), 1.03 $(3 \mathrm{H}, \mathrm{s}, \mathrm{H}-21), 5.16(1 \mathrm{H}, \mathrm{dd}, \mathrm{J}=15.15,8.59 \mathrm{~Hz}, \mathrm{H}-22)$, $5.02(1 \mathrm{H}, \mathrm{dd}, \mathrm{J}=15.17,8.66 \mathrm{~Hz}, \mathrm{H}-23), 1.54(1 \mathrm{H}$, obsc, $\mathrm{H}-24), 1.45$ (1H, obsc, H-25), 0.85 (3H, s, H-26), 0.81 $(3 \mathrm{H}, \mathrm{s}, \mathrm{H}-27), 1.18$ (2H, obsc, H-28), $0.68(3 \mathrm{H}, \mathrm{s}, \mathrm{H}-$ 29). ${ }^{13} \mathrm{C}-\mathrm{NMR} 150 \mathrm{MHz}, \mathrm{CDCl}_{3}: \delta 37.26(\mathrm{C}-1), 31.67$ (C-2), 71.82 (C-3), 42.31 (C-4), 140.76 (C-5), 121.73 (C-6), 31.91 (C-7), 45.84 (C-8), 50.14 (C-9), 36.52 (C10), 21.10 (C-11), 39.78 (C-12), 42.22 (C-13), 56.77 (C-14), 24.37 (C-15), 26.08 (C-16), 55.96 (C-17), 12.06 (C-18), 19.40 (C-19), 40.50 (C-20), 21.23 (C-21), 138.33 (C-22), 129.28 (C-23), 51.25 (C-24), 31.88 (C25), 19.83 (C-26), 18.99 (C-27), 25.42 (C-28), 11.87 (C-29). COSY correlations $\mathrm{H} / \mathrm{H}: 2 / 3,1 \mathrm{a} ; 3 / 4 \mathrm{a} ; 7 \mathrm{~b} / 7 \mathrm{a}$; 6/7a, 7b. HMBC correlations C/H: 1/19; 2/4a; 3/1b, 2, 4, 1a; 4/6; 5/19, 1b, 4, 1a, 6, 7b; 6/4; 7/6; 9/19; 10/4, 6, $8 ; 12 / 18 ; 13 / 18 ; 14 / 18 ; 17 / 21,22 ; 18 / 12,17 ; 20 / 22,23$; $21 / 22$; 22/21, 20, 23; 23/22, 20, 25, 28; 24/22, 23, 26; 25/27; 26/27; 28/23. EIMS (70 eV) m/z (\%): $412\left(\mathrm{M}^{+}\right.$, 38), 396 (75), 381 (40), 329 (87), 273 (43), 255 (53), 231 (98), 213 (100), 199 (64), 163 (50), 161 (60), 145 (67), 133 (48), 105 (40), 91 (50), 81 (53), 79 (29). 
Table 3: The $\log \mathrm{P}$ value and cytotoxic activity of pure compounds extract from hexane and ethyl acetate fraction of leaves and twigs of $F$. virosa

\begin{tabular}{llll}
\hline & & IC at $125 \mu \mathrm{g} \cdot \mathrm{mL}^{-1}(\%)$ \\
Compound & $\log \mathrm{P}^{\mathrm{a}}$ & $\mathrm{K} 562$ & K562/Adr \\
\hline Friedelin (1) & 9.13 & No activity & No activity \\
Heptanolide (2) & 8.53 & 34 & 18 \\
Epifriedelanol (3) & 8.81 & No activity & 26 \\
Stigmasterol (4) & 7.82 & 5 & 13 \\
Betulinic acids (5) & 7.38 & 100 & 100 \\
\hline a Canc
\end{tabular}

${ }^{a}$ : Calculated from chemical structure by using ChemBioDraw Ultra 11.0

Betulinic acids (5): White powder from $\mathrm{Me}_{2} \mathrm{CO}$ : $\mathrm{MeOH}$, m.p. $279.5-281.3^{\circ} \mathrm{C}$. (Lit ${ }^{[21]}$ m.p. $\left.282^{\circ} \mathrm{C}\right)$. UV (MeOH) $\lambda_{\max } n m(\log \varepsilon): 223$ (3.04). IR (KBr) $v_{\max }$ : 3464 (OH stretching), $1686(\mathrm{C}=\mathrm{O}$ stretching of carboxylic acid), 1639 (C = C stretching), 2943-2870 $\mathrm{cm}^{-1}$. ${ }^{1} \mathrm{H}$ and ${ }^{13} \mathrm{C}-\mathrm{NMR}$ data: Table 1. COSY correlations $\mathrm{H} / \mathrm{H}: 2 / 3 ; 6 / 7 ; 18 / 19 ; 21 / 22$. HMBC correlations: Table 2. EIMS (70 eV) m/z (\%): 456( $\mathrm{M}^{+}$, 7), 438(9), 411(5), 395(28), 248 (88), 228(5), 207(37), 203(30), 190(50), 189(100), 175(46), 119(47), 93(38).

The antiproliferation activity of compounds: Bioactive investigation of purified compounds from hexane and ethyl acetate fraction of leaves and twigs of $F$. virosa showed that, among the five compounds tested, only compound 5 displayed a strong antiproliferative activity on K562 and K562/Adr cell lines. We found that the $\mathrm{IC}_{50}$ value of compound 5 is $9.7 \pm 2.1 \mu \mathrm{g} \cdot \mathrm{mL}^{-1}$ $(21.2 \pm 4.6 \mu \mathrm{M})$ and $7.1 \pm 0.7 \mu \mathrm{g} . \mathrm{mL}^{-1}(15.5 \pm 1.5 \mu \mathrm{M})$ for $\mathrm{K} 562$ and $\mathrm{K} 562 / \mathrm{Adr}$ respectively, while the $\mathrm{IC}_{50}$ of compound 1, 2, 3 and 4 are undetectable. The \% IC values of all compounds at the concentration of $125 \mu \mathrm{g} \cdot \mathrm{mL}^{-1}$ were presented in Table 3 .

\section{DISCUSSION}

Compound 1 exhibited $\left[\mathrm{M}^{+}\right]$peak at $\mathrm{m} / \mathrm{z} 426$ in the EIMS corresponding to a molecular formula $\mathrm{C}_{30} \mathrm{H}_{50} \mathrm{O}$. Its IR (KBr) spectrums showed the absorption bands at $v_{\max } 1715 \mathrm{~cm}^{-1}$ (for 6-membered ring ketone) and 2927 , $2870 \mathrm{~cm}^{-1}$ (for $\mathrm{C}-\mathrm{H}$ stretching of $\mathrm{sp}^{3}$ hybridization). The ${ }^{1} \mathrm{H}-\mathrm{NMR}$ spectrum (Table 1) of 1 displayed a characteristic low field shift of multiplet for $\alpha$-proton ketone at position 2 and 4 at $\delta 2.42$ and 2.25, as well as the one secondary and seven tertiary methyls of the friedelane moiety were observed in the ${ }^{1} \mathrm{H}-\mathrm{NMR}$ spectrum as a doublet at $\delta 0.89(\mathrm{~J}=8.0 \mathrm{~Hz}, \mathrm{Me}-23)$ and singlet at $\delta 0.73,0.87,0.95,2(1.01), 1.05$ and 1.18 , respectively. A part from the most very low field shifts carbon signal at $\delta 213.32$ represented the 3-keto group of friedelin. Additionally, the presence of the two methylene carbons connected to a carbonyl group were characteristic by the low-field shifts than normal at $\delta$ 41.54 and 58.23, respectively. The mass fragmentation ions in the mass spectrum of 1 at $\mathrm{m} / \mathrm{z} 426\left[\mathrm{M}^{+}\right], 411$, $341,302,273,246,231,109$ (base peak) and 67 were useful in obtaining the structure of $1^{[19]}$. The presence of the carbonyl group was confirmed as evidenced by the fragment ions at m/z 109 for $\mathrm{C}_{7} \mathrm{H}_{9} \mathrm{O}^{+}$. Furthermore, the fragment ions at $\mathrm{m} / \mathrm{z} 273,341$ and 302 were showed specific characteristic of $\mathrm{m} / \mathrm{z}$ values of ions in friedelane derivatives ${ }^{[22]}$. Compound 1 was finally proved to be friedelin by direct comparison of its ${ }^{1} \mathrm{H}$ and ${ }^{13} \mathrm{C}-\mathrm{NMR}$ (Table 1) spectral data with those reported in the literature ${ }^{[19]}$. The results from 2D NMR experiments supported the assignments of protons and carbons in the structure (Table 1). In order to gain more information about the structure activity relationship, the isolated friedelin (1) was modified hence the oxidative transformation of ring A of friedelin was undertaken. The Baeyer Villiger oxidation of friedelin (1) with MCPBA in $\mathrm{CH}_{2} \mathrm{Cl}_{2}$ at room temperature for overnight afforded the heptanolide (2) (60\% yield). The heptanolide (2) possesses a supplementary oxygen atom compared to compound 1, by their EIMS at $\mathrm{m} / \mathrm{z} 442\left[\mathrm{M}^{+}\right]$ for $2\left(\mathrm{C}_{30} \mathrm{H}_{50} \mathrm{O}_{2}\right)$. The IR $(\mathrm{KBr})$ spectra showed the absorption bands corresponding to the $\mathrm{C}=\mathrm{O}$ stretching of 7-membered ring lactone at $1737 \mathrm{~cm}^{-1}$. The ${ }^{1} \mathrm{H}$ and ${ }^{13} \mathrm{C}$-NMR spectral data of 2 was quite similar to those of 1 with some difference observed in ring A. With respect to the analogous signals observed in 1 , the downfield shifts of the C-2 and C-4 signals at $\delta 2.64$ $(\mathrm{dd}, \mathrm{J}=13.4,6.6 \mathrm{~Hz}), 2.52(\mathrm{t}, \mathrm{J}=12.8 \mathrm{~Hz})$ and $4.22(\mathrm{q}$, $6.4 \mathrm{~Hz}$ ), respectively. The $\mathrm{C}-4$ signals in the ${ }^{13} \mathrm{C}-\mathrm{NMR}$ spectra at $\delta_{\mathrm{C}} 84.94$ for compound 2 was due to the $\gamma$ effect of the C-5-C-6 bond and the C-3 carbonyl in the ring A lactone. Other connectivities were confirmed by 2D NMR correlation experiments (Table 2). Compound 3 was obtained as white needles from $\mathrm{CH}_{2} \mathrm{Cl}_{2}: \mathrm{MeOH}$. The IR (KBr) spectrum of 3 exhibited the absorption bands at $3475 \mathrm{~cm}^{-1}$ (O-H stretching) and 2933-2869 $\mathrm{cm}^{-1}$ (for $\mathrm{C}-\mathrm{H}$ stretching of $\mathrm{sp}^{3}$ hybridization) which suggested that 3 had friedelane skeleton. The EIMS of 3 showed the $\left[\mathrm{M}^{+}\right]$at 428 , corresponding to a molecular formula of $\mathrm{C}_{30} \mathrm{H}_{52} \mathrm{O}$. Compound 3 is clearly related to compound 1, except that 3 has one hydroxyl group in the structure. The ${ }^{1} \mathrm{H}$ and ${ }^{1} 3 \mathrm{C}$-NMR spectra of compound 3 were almost same as those of compound 1 . The differences were the absence of a ketone signal at $\delta$ 213.32 (C-3 in 1) and the presence of hydroxyl group $(\delta$ $3.73, \mathrm{H}-3$ and $\delta 72.77, \mathrm{C}-3$ ) in 3 . Based on the above mentioned data and the reported chemical structure of triterpene, they were in good agreement with 
epifriedelanol, which was reported in the literature ${ }^{[23]}$. Furthermore, the structure of compound 3 was finally proved by single-crystal X-ray diffraction and the X-ray ORTEP diagram is as shown in Fig. 1. Compound 5 was obtained as a white powder from $\mathrm{Me}_{2} \mathrm{CO}: \mathrm{MeOH}$. The EIMS spectrum exhibited a $\left[\mathrm{M}^{+}\right]$ions peak at $\mathrm{m} / \mathrm{z}$ 456 corresponding to a molecular formula at $\mathrm{C}_{30} \mathrm{H}_{48} \mathrm{O}_{3}$. Its IR spectrum displayed the carboxylic carbonyl absorption at $1686 \mathrm{~cm}^{-1}$. In additionally, the strong absorption band at $3464 \mathrm{~cm}^{-1}$ was revealed the $\mathrm{O}-\mathrm{H}$ stretching. The fragmentation ions in the mass spectrum of 5 at $\mathrm{m} / \mathrm{z} 456\left(\mathrm{M}^{+}, 7\right), 438(9), 411(5), 248(88), 228(5)$, 207(37), 203(30), 189(100) were also useful in obtaining the structure $5^{[21]}$. The ions at $\mathrm{m} / \mathrm{z} 438$ and 248 were the results of carboxylic group in the structure. Furthermore, independent evidence that angular carboxylic group is readily eliminated from triterpenes was provided by the EIMS spectrum, which exhibited an intense M-45 peak (411) ${ }^{[22]}$. The ${ }^{1} \mathrm{H}-\mathrm{NMR}$ spectrum of 5 exhibited characteristic proton signals of the isopropenyl group a downfield singlet of vinylic methyl at $\delta 1.80$ and a pair of broad singlets due to exomethylene protons at $\delta 4.78$ and 4.95 . The multiplet at $\delta 3.46(\mathrm{~m})$ in the spectrum of 5 was typical for a triterpene with 3-hydroxy substituent. The ${ }^{13} \mathrm{C}$-NMR spectrum data of $\delta_{\mathrm{C}} 179.66$ which the most downfield signal confirmed the presence of the carbonyl of carboxylic group. In order to obtain more information about the location of carboxylic group in compound 5, a 2D NMR HMBC was carried out. The correlations observed at $\delta 1.76(\mathrm{H}-18)$ and $\delta 1.57(\mathrm{H}-22)$ were exhibited the carbon signal at $\delta 179.66$ (C-28). In addition to the carbon signal at $\delta 110.20$ indicated that the presence of exomethylene carbon in the structure.

By the result of antiproliferation activity on cancer cell lines, we can determine the $\mathrm{IC}_{50}$ value only in compound 5. In fact, we observed that the aqueous solubility of compound 1, 2, 3 and 4 was very low. The $\log \mathrm{P}$ values which characterized the solubility of the compounds were calculated from their chemical structure using ChemBioDraw Ultra 11.0 and were printed in Table 3. According to this calculation, compound 5 has the smallest $\log \mathrm{P}$ value. Comparing to the chemical structure and bioactivity, the substitution of hydroxyl group on C-3 of compound 3 resulted in a decrease of the $\log \mathrm{P}$ value and an increase in the cytotoxic activity on both cancer cell lines, while the oxidative transformation on ring A of 1 resulted in a higher cytotoxicity on K562/Adr. However, the generation of growth inhibition curves for all compounds except compound 5 was rendered difficult due to the low aqueous solubility of these compounds.

\section{CONCLUSION}

In conclusion, it is interesting to note that although the occurrence of triterpenoids have been reported in several species of plants or in living system, compounds possessing significant antiproliferative activity are particularly rare. Our research demonstrated that betulinic acid was the triterpene compound displaying the higher antiproliferative activity. In addition, this compound is easily extracted from the $F$. virosa. Our work emphasized the importance of the compound solubility parameter as the key obstacle against its in vitro antiproliferative evaluation on human cell lines.

\section{ACKNOWLEDGEMENT}

The researches wish to thank the Center of Excellence for Innovation in Chemistry (PERCH-CIC) for financial support and the National Research Council of Thailand (NRCT), The Royal government, grants no. 004/2008. Furthermore, we are very grateful to Asst. Prof. Dr. Chaveng Pakawatchai, Department of Chemistry, Faculty of Science, Prince of Songkla University, Hat Yai, Thailand for making structure by $\mathrm{X}$-ray diffraction analysis. Moreover, the researcher thanks to Dr. Manuel Garrigos for English editing.

\section{REFERENCES}

1. Smitinand, T., 2001. Thai Plant Name. Revised Edn., The Forest Herbarium Royal Forest Department, Pra Cha Chon Co., Ltd., ISBN: 974-88385-0-1, pp: 245.

2. Kaou, A.M., V. Mahiou-Leddet, S. Hutter and S. Ainouddine et al., 2008. Antimalarial activity of crude extracts from nine African medicinal plants. J Ethnopharmacol., 116: 74-83. DOI: 10.1016/j.jep.2007.11.001

3. Muthaura, C.N., G.M. Rukunga, S.C. Chhabra and S.A. Omar, 2007. Antimalarial activity of some plants traditionally used in treatment of malaria in Kwale district of Kenya. J. Ethnopharmacol., 112: 545-551. DOI: 10.1016/j.jep.2007.04.018

4. Tanko, Y., M.A. Okasha, G.M. Magaji, M. Yerima, A.H. Yaro, M.I.A.S. and A. Mohammed, 2008. Anti-diabetic properties of Securinega virosa (Euphorbiaceae) leaf extract. Afr. J. Biotechnol., 7: 22-24. http://www.academicjournals.org/ ajb/abstracts/abs2008/4Jan/Tanko\%20et\%20al.htm

5. Moshi, M.J., M.C. Kapingu, F.C. Uiso, Z.H. Mbwambo and R.L.A. Mahunnah, 2000. Some pharmacological properties of an aqueous extract of Securinega virosa roots. Pharm. Biol., 38: 214-221. DOI: 10.1076/1388-0209(200007)38:3;1-S;FT214 
6. Dickson, R.A., P.J. Houghton, P.J. Hylands and S. Gibbons, 2006. Antimicrobial, resistancemodifying effects, antioxidant and free radical scavenging activities of Mezoneuron benthamianum Baill., Securinega virosa Roxb. and willd. and Microglossa pyrifolia Lam. Phytother. Res., 20: 41-45. DOI: 10.1002/ptr.1799

7. Magaji, M.G., A.H. Yaro, A. Mohammed, A.U. Zezi, Y. Tanko and T.Y. Bala, 2007. Preliminary antidiarrhoeal activity of methanolic extracts of Securinega virosa (Euphorbiaceae). Afr. J. Biotechnol., 5: 2752-2757. http://www.academicjournals.org/AJB/PDF/pdf200 7/17Dec/Magaji\%20et\%20al.pdf

8. Nyasse, B., J. Nono, B. Sonke, C. Denier and C. Fontaine, 2004. Trypanocidal activity of bergenin, the major constituent of Flueggea virosa, on Trypanosoma brucei. Pharmazie, 59: 492-494. http://www.ncbi.nlm.nih.gov/pubmed/15248469

9. Pu, H.L., X. Huang, J.H. Zhao and A. Hong, 2002. Bergenin is the antiarrhythmic principle of Fluggea virosa. Planta Med., 68: 372-374. DOI: $10.1055 / \mathrm{s}-2002-26758$

10. Magaji, M.G., J.A. Anuka, I. Abdu-Aguye, I. Abdu-Aguye, A.H. Yaro and I.M. Hussaini, 2008. Behavioural effects of the methanolic root bark extract of Securinega virosa in rodents. Afr. J. Tradit. Compl. Altern. Med., 5: 147-153. http://ajol.info/index.php/ajtcam/article/view/31266

11. Freiburghaus, F., E.N. Ogwal, M.H. Nkunya, R. Kaminsky and R. Brun, 1996. In vitro antitrypanosomal activity of African plants used in traditional medicine in Uganda to treat sleeping sickness. Trop. Med. Int. Health, 1: 765-771. DOI: 10.1111/j.1365-3156.1996.tb00108.x

12. Pedersen, M.E., H.T. Vestergaard, S.L. Hansen, S. Bah, D. Diallo and A.K. Jager, 2009. Pharmacological screening of malian medicinal plants used against epilepsy and convulsions. J. Ethnopharmacol., 121: 472-475. DOI: 10.1016/j.jep.2008.11.006

13. Gan, L.S., C.Q. Fan, S.P. Yang, Y. Wu, L.P. Lin, J. Ding and J.M. Yue, 2006. Flueggenines A and B, two novel $\mathrm{C}, \mathrm{C}$-linked dimeric indolizidine alkaloids from Flueggea virosa. Org. Lett., 8: 2285-2288. DOI: $10.1021 / \mathrm{ol060551f}$
14. Honda, T., H. Namiki, M. Watanabe and H. Mizutani, 2004. First total synthesis of (+)-viroallosecurinine. Tetrahedron Lett., 45: 5211-5213. DOI: 10.1016/j.tetlet.2004.05.031

15. Dehmlow, E.V., M. GuntenhÖner and T. Van Ree, 1999. A novel alkaloid from Fluggea virosa: 14, 15epoxynorsecurinine. Phytochemistry, 52: 1715-1716. DOI: 10.1016/S0031-9422(99)00208-3

16. Nakano, T., T.H. Yang and S. Terao, 1963. Studies on the alkaloids of Securinega virosa Pax. et hoffm. I: Structure of virosecurinine. Tetrahedron, 19: 609-619. DOI: 10.1016/S0040-4020(01)98547-3

17. Tatematsu, H., M. Mori, T.H. Yang, J.J. Chang, T.T. Lee and K.H. Lee, 1991. Cytotoxic principles of Securinega virosa: Virosecurinine and viroallosecurinine and related derivatives. $\mathrm{J}$. Pharm. Sci., 80: 325-327. DOI: 10.1002/jps.2600800408

18. Wai-Haan, H., 1. Man-Moon and L. Yuk-Chun, 1977. Triterpenoids from two Hong Kong Euphorbiaceae species. Phytochemistry, 16: 607-608. DOI: 10.1016/0031-9422(77)80030-7

19. Thanakijcharoenpath, W. and O. Theanphong, 2007. Triterpenoids from the stem of Diospyros glandulosa. Thai J. Pharm. Sci., 31: 1-8. http://www.pharm.chula.ac.th/tjps/ContentVol31N o1_2/Art1V31No1-2.pdf

20. Shen, G., S.R. Oh, B.S. Min, J. Lee, K.S. Ahn, Y.H. Kim and H.K. Lee, 2008. Phytochemical investigation of Tiarella polyphylla. Arch. Pharm. Res., 31: 10-16. DOI: 10.1007/s12272-008-1113-X

21. Choi, S.Z., M.C. Yang, S.U. Choi and K.R. Lee, 2006. Cytotoxic terpenes and lignans from the roots of Ainsliaea acerifolia. Arch. Pharm. Res., 29: 203-208. DOI: 10.1007/BF02969394

22. Budzikiewics, H., C. Djerassi and D.H. Williams, 1964. Structure Elucidation of Natural Products by Mass Spectrometry. Holden-Day Inc., pp: 132-139. http://openlibrary.org/b/OL5917466M/Structure_el ucidation_of_natural_products_by_mass_spectrom etry

23. Kim, D.K., J.P. Lim, J.W. Kim, H.W. Park and J.S. Eun, 2005. Antitumor and antiinflammatory constituents from Celtis sinensis. Arch. Pharm. Res., 28: 39-43. DOI: 10.1007/BF02975133 